\title{
The Innovation and Development of School-running Mode of Continuing Education in the Internet Age
}

\author{
Weiyu CHEN, Jin DING \\ Beijing Wuzi University, Beijing, China
}

\begin{abstract}
Internet age, the speed of the knowledge update rapidly. Continuing education as an important part of the implementation of the national development strategy, is the driving force to enhance the future competitiveness. When continuing education is facing with great opportunities for development, it will also faces new challenges. Based on respect for the laws of education, continuing education needs to innovate the pattern of talents training, position the direction of development accurately and solve the problem of school-running mechanism in the process of development as soon as possible.
\end{abstract}

KEYWORD: The Internet Age, Continuing Education, School-running Mode

\section{INTRODUCTION}

Talents cultivation must conform to the needs of the development of social economy. In the Internet age, the rapid development of information technology breaks the boundaries of time and space of education. It is the development trend of continuing education in the Internet age to intensify reform, change traditional inflexible, rigid mode of teaching, and innovate talents training modes with the aid of diversification and individuation of modern information technology fully.

\section{A NEW OPPORTUNITY, THE INTERNET AGE GIVES TO THE DEVELOPMENT OF CONTINUING EDUCATION IN COLLEGES AND UNIVERSITIES}

The Internet age contains the development opportunities of continuing education. Labor transfer between the industrial structure, the boundaryless career and information technology bring new learning style, those are promoting the continuing education of our country working from the edge gradually towards the centre of higher education.

\subsection{The adjustment of industrial structure and the migration of talents demand}

Internet technology has accelerated a series of changes in Chinese economic field, the economic growth mode is different from any other time, millions of laborer are transferred between different industries every year, the transformation of industrial structure has given rise to tens of thousands of new and re-employment laborer. The adjustment of industrial structure, therefore, will definitely put forward new tasks 、 new subjects to continuing education, accelerate continuing education to change teaching contents $、$ teaching means and teaching methods, and provide a new space for the development of continuing education.

\subsection{Lifelong learning under the background of no boundary occupation career}

In the Internet age, new science, new knowledge, and new technology emerge in endlessly, breaking the concept of life-long career. Boundaryless career has subverted the two mode stage: "first half of life education, life after busy work." and "live and learn "is no longer stay in concept hierarchy. Professionals need to continuously accept continuing education to become the norm, continuing education to cultivate talents with the diversification of its unique mode has become the effective way for Chinese human capital accumulation under the background of no boundary occupation career.

\subsection{The way of learning in the Internet age change}

The convenience in information dissemination, form innovation and instant interaction of Information technology provides a U-Learning learning mode for people without time and geographical restriction. 
The process of economic development has proved that: in the Internet age, learning styles carried by information technology will become a new mode for the development of continuing education, subtly change the organization and operation mode of continuing education institutions, and bring more development opportunities for continuing education.

\section{THE PROBLEM IN SCHOOL-RUNNING MODES OF CONTINUING EDUCATION IN COLLEGES AND UNIVERSITIES}

No matter ordinary higher education or continuing education, the education quality is a key issue to the sustainable development. At present, the schoolrunning modes of continuing education in our country mainly are night college, correspondence, self-study exam, network distance education, and other academic education. in addition, there are onthe-job graduate student education, graduate course study, pre-job and on-the-job training, foreign cooperation to running schools, and other nonacademic education. Academic education is still the mainstream of education. In fact, although these school-running modes meet some requirements of the development of continuing education in a certain development period, it also should be admitted that continuing education does exist some problems in the development process, if we use a strategic view to look at its education function and effect.

\subsection{Lacking characteristic teaching system}

In the long trend of paying more attention to degree than ability, continuing education is a optional remedial measure for academic education. Formal education, as the main body of the education system in colleges and universities, makes continue education deeply branded with the mark of general education. Continuing education teaching plan mostly follows and imitates the full-time undergraduate practice, and borrows many aspects from ordinary university education, such as Management hierarchy construction, education goal design, majors and courses setting, teaching methods and teaching methods, and teachers certification and management assessment. It is not close to the characteristics of on-the-job continuing education and social practice, and not form the unique features of continuing education.

\subsection{Rigid personnel training mode}

The talents training mode of traditional continuing education repeats the same "production line" mode of "introduction to adult test, listening to lectures fool and examination pass." Continuing education mainly in class teaching focuses on imparting theoretical knowledge, and ignores the cultivation of students' practical ability, leading to real needs and personnel training out of touch and students proper technical skills lacking, and holding a diploma to work is difficult to adapt to the practical needs.

\subsection{The laggard website construction of continuing education}

Education website construction being successful or not, is one of the important indexes to measure the level of continuing education. In the rapid progress of Internet technology today, one of the hardware obstacles to the development of continuing education is the construction lag of continuing education website, which is difficult to match with the development of information technology. Although many colleges and universities have independently set up their own continuing education websites, many education websites' construction are lagging behind the demand of the modern education technology and a lot of the content of the site also stay on plate set of routinization 、 rigid schedule and program content introduction, and so on. Investigate its reason, contain many factors, but the key lies in the degree of not enough attention, and separation from the talents training targets of social needs.

\subsection{Urgently integrate teachers}

The teachers' team construction of continuing education school mainly rely on their own professional teachers in colleges and universities. In recent years, continuing education didn't get the attention they deserve, leading to the limitation of teachers' teaching ability, serious shortage of teachers, and other issues universally. Especially some pure school teachers, lacking sufficient practical experience, can only be scripted and appear easily asymmetry phenomenon of supply and demand of knowledge, noting easily improving teaching quality. Scattering and lack of professional talents in team building restrict continuing education to develop in depth and breadth.

\subsection{The under-funded school funds}

The under-funded school funds is a sticking point to restrict the development of continuing education from the actual operation situation. On the one hand, the charge standard of continuing education is far below the cost of running and remain unchanged for many years; on the other hand, with the fast development of the Internet age, continuing education needs a lot of special funds to seek new development, employ higher level teachers, improve school means, develop key projects and, etc. So, we need to intensify investment in continuing education, make relatively flexible fiscal policy, and carry out 
the special funds for the characteristics of education development of colleges and universities.

\section{SCHOOL-RUNNING MODE INNOVATION OF IMPROVING TEACHING QUALITY}

The development of continuing education must stick to the times' pulse. Start from the reality needs of social economy, making multi-level、 many forms and multi-channel innovation for the personnel training mode of continuing education, are the important problems that must be addressed in current.

\subsection{The distinctive feature of school-running goals}

Continuing education is different from the ordinary higher education, it is the follow-up education outside of the traditional subject education. On one hand, it should be cleared that continuing education is practical education of on-the-job personnel, so that orientation of educational goals must also be different from the ordinary education because of the different education objects. On the other hand, the goals of academic continue education and nonacademic continue education should be positioned respectively. Academic continue education should focus on knowledge application and systemic teaching, highlighting the theoretical foundation and developing potential in professional Settings 、 teaching contents 、 teaching materials selection, teachers provision, etc. Non-academic continuing education needs to face the transformation of economic structure and the social demands, focusing on cultivating students' learning ability to solve practical problems.

\subsection{Flexible application of school-running mechanism}

Mechanism innovation is the key to promote the development of continuing education in the direction of specialization、 large scale, and diversification. The teaching should meet the on-the-job personnel's need for updated knowledge and skills constantly; continuing education, with the help of information technology and online synchronous teaching way, needs to solve the conflict of engineering and the contradiction of time and space. What's more, hierarchical continuing education training scheme should be customized based on different learning needs. For professional and technical personnel, we should attach importance to the teaching of new technologies, new methods and new theory, and keep tracking the frontiers of knowledge; For managers, we need to set up the interdisciplinary courses and optimize knowledge structure; For academic continuing education, we have to pay attention to the teaching of basic theoretical knowledge and guide students the targeted learning of professional knowledge; For non-academic training, we'd better integrate into occupation qualification examination courses and meet the demand of professional development;

\subsection{The perfect teaching quality evaluation}

The evaluation of continuing education quality often become a mere formality and assessment of teaching quality long-term emphasis on full-time education. Continuing education must clear quality evaluation targets as soon as possible and establish a scientific evaluation index system. And, of course, the standard of teaching quality evaluation, mainly still should examine whether continuing education meet the needs of the society and can promote the development of economy. Therefore, the main body participation in continuing education evaluation, in addition to academic experts - employers, labour market should also be involved. the quality evaluation system related to meet market demands is able to consider whether many aspects, such as talents training schemes, professional settings 、 teaching contents teaching methods and teaching means really accord with the internal law of education synthetically and three-dimensionally, and whether students realize their own value.

\subsection{Fully functional information construction}

In the Internet age, the technology based on global resource sharing provides the possibility for the informationization of continuing education. Education technology expands the career boundary of continuing education, continuing education institutions 、 teachers and students can be dispersed geographically, knowledge transfer can quickly realized through the internet. How to play the advantage of information technology in rapid spread diverse forms and real-time interaction? First of all, you should put continuing education into the unified information platform of colleges and universities, make the excellent course digital, let different System courseware can be used through the network platform, and promote high-quality education resources shared between continuing education and academic education; secondly, you have to integrate domestic and foreign education resources, make web resources database integrated between schools, build network education alliance, and enrich the existing education resources database; Thirdly, you can use computer technology to achieve the timely sharing of real-time interaction, to provide more personalized service and better collaborative learning environment between teachers and students. 


\subsection{Close to the practice of the curriculum}

The emerging professions promoted by Internet age require continuing education to adjust the curriculum in the practice of the latest development, teaching contents are derived from the choosing, refining and reconstruction of theoretical knowledge and production practice. The professional Settings of continue education should be guided by market demands, and adjust professional direction timely according to the variation of talents markets; The curriculum of continuing education need to open curriculum systems oriented by positions demands, and ensure that the teaching contents can provide students with a broader space for development; The teaching contents of continue education not only have to timely use the latest achievements in the development of science and technology to enrich itself, but also have to fully combine the students' vocational needs; The teaching links of continuing education need to increase the cases teaching and empirical teaching contents, and combine theory and cases analysis to enhance student's ability to use the theoretical knowledge. We should make teaching extended from class to enterprise, select the key problems closely related to the students' profession to exchange on the site, and enhance students' understanding and application of theoretical knowledge.

\subsection{Reasonable structure of the teaching staff}

Reasonable structure 、 excellent quality and distinctive teaching staff provide talents guarantee for continuing education to enhance the quality. Continuing education need to strengthen the construction of teachers team, adhere to the opendoor education according to the characteristics of students from the front line of production, establish a high level of external teachers and experts database geared by the needs of society, improve the quality and level of continuing education activities. The "double division" with good professional quality, not only own theoretical knowledge in teaching, but also possess rich practical experience, they can impart prospective technology for students in time to enhance the unique quality of continuing education, and meet the diverse society needs for continuing education to the maximum limit. In addition, they are effective ways to carry out the performance appraisal of teachers and introduce competition mechanism to improve teachers' teaching level.

\section{CONCLUSION}

In the Internet age, continuing education should conform to the objective requirement of social and economic development, make school-running goal clear, straighten the school-running mechanism, promote continuing education to transform from quantity to quality benefit type with first-class teaching staff 、 excellent teaching quality and practical teaching system, outstand the pertinence and professionalism of talents training, and cultivate applied talents which are urgent for local economic development.

\section{REFERENCES}

[1] Dong Sheng, Sun Xiaoxia. The development trend of adult education in Harmonious Society. Chinese adult education, 2009, (24): 18

[2] Yan Xing, Chang Yaping. Micro-blog review. Journal of information, 2011 (9): 61

[3] Zhang Wenzhong, Zong Bojun. The development trend of China's Adult Education in Colleges and universities and the reform of management system. Continuing education research, 2010, (3): 24 